\title{
THE EFFECT OF THE MIND MAP METHOD ON THE STUDENTS' MEMORY IN THEMATIC LEARNING
}

\author{
Dea Amelia Harits ${ }^{1 *}$ and Mizaniya ${ }^{2}$ \\ 1,2Primary School Teacher Education Department \\ Universitas Islam Negeri Sunan Kalijaga, Yogyakarta, Indonesia \\ *Email: deaameliaharits@gmail.com
}

\author{
Website: \\ https://jurnal.uinantasari.ac.id/index.php/adzka \\ Received: 4 July 2020; Accepted: 20 April 2021; Published: 23 June 2021 \\ DOI: $\underline{\text { 10.18952/aladzkapgmi.v11i1.3789 }}$
}

\begin{abstract}
Mind mapping is a method that can optimize students' memory, because it uses images, lines, colors, and symbols that can stimulate the child's double senses, in addition mind mapping can also maximize their brain abilities. The purpose of this study was to find out the influence of mind map method on the memory of learners in thematic learning in class IV MI Ma'arif NU 02 Tamansari. This research is a type of pre-experimental research conducted with the design of one group pretest posttest. The population in this study was all students in grade IV MI Ma'arif NU 02 Tamansari. Data collection techniques used in the form of observation, interviews, tests, and documentation. Test instruments use a type of short fill test that has been through the analysis of validity and reliability. Data analysis techniques use prerequisite test analysis in the form of normality and homogeneity test, and hypothesis test using statistical test paired sample $t$ test. The results showed that the mind map method affects the memory of learners. This was demonstrated by Sig. (2-tailed) t test result with a significance of 0.000 less than 0.05 . So, $\mathrm{H}_{a}$ was accepted and $\mathrm{H}_{o}$ was rejected, meaning that the mind map method affects the memory of the learners.
\end{abstract}

Keywords: power of memory; mind map method; thematic learning

\section{INTRODUCTION}

Efforts to update and extend the quality of education are carried out in thematic learning. To fully minimize the substance of curriculum lessons, thematic learning is used (Suryosubroto, 2009). Student-centered, gaining direct experience in learning, thematic learning adheres to the principles of PAKEM learning, not very clear in the separation between subjects, subjects are provided with various material concepts, thematic learning is flexible (elastic), learning outcomes are interested (hobby) and the desire (needs) to be adjusted to the students are the characteristics of thematic learning in the learning model at the SD / MI education level (Rusman, 2011).

In SD / MI (elementary school) in the 2013 curriculum, all subjects have been integrated with thematic learning. The integrated learning model (integrated teaching) is thematic learning. Thematic learning is a learning system that allows students to actively explore (investigate) and get holistic, meaningful, and authentic scientific concepts and principles, individually or in groups. (Rusman, 2011). Learning these subjects is a learning method that deliberately connects several aspects in the curriculum and between disciplines. Through this integration, students will get complete knowledge and skills, so that learning becomes meaningful for students (Majid, 2004). It is concluded that subject learning is 
learning from a subject related to a subject, for example between one learning area and another, by using various learning experiences so that learning is more meaningful.

Basic education at the elementary school level on thematic learning material has a large position on memory skills. A deliberate approach to learning that combines several aspects both between and within-subjects is thematic learning. Students in learning will be meaningful in their entirety by combining other materials or subjects in order to gain proficiency and knowledge gained in learning. (Majid, 2004). Direct \& factual experience by linking material concepts between other subjects is the way students learn and understand concepts in thematic learning is a meaningful meaning.

Everything that is around a person, in fact, is very beneficial to humans if humans are able to use their intellect (cognitive) to think about it. Therefore, when a student can use the concept of thinking, it is the task of education to develop it. Without the cognitive realm, it is difficult to imagine a child being able to think. Furthermore, without the ability to think, it is very unlikely that a child will be able to understand, believe, and apply the things he catches from his surroundings, both in the form of subject matter, moral messages from family and peer circles (Juwantara, 2019).

The cognitive process applied is always related to the teaching process in everyday life and school. The process of learning, exploring, remembering, and responding is a cognitive process. The cognitive realm is an activity that involves the brain according to Bloom. The skills to remember, explore, apply, study, integrate, and assess skills are thinking skills related to the cognitive realm (MA, 2010). According to Bloom, the cognitive realm learning objectives are divided into 6 levels according to the lowest to the highest level which is denoted by $\mathrm{C}$ (Cognitive), namely at the first level $\mathrm{C} 1$, namely knowledge, which emphasizes the ability to recall material that has been studied such as knowledge of terms, special facts, conventions, classifications and categories, criteria and methodology. This level is the lowest level but is a prerequisite for the next level.

If the implementation of teaching and learning activities of the teacher does well in the classroom so that it makes students have better memory, the students in understanding the material will be good. Some educators almost experience one of the problems, namely the lack of students' memory in the subject matter (Lubis, 2014). In the learning process, there are several materials presented. This makes the memory or the level of memos received by children more and more, especially students who always receive material every day during class learning. The low memory of students is indicated by the difficulty of students in remembering the subject matter and this will make the learning process slow. (Lubis, 2014).

Memory (memory) comes from English. In the book "Introduction to General Psychology", Bimo Walgito argues that memory is a language translation of memory (Bimo, 2010). Memory in the mental dictionary is defined as a complex mental function to recall things that have been experienced and learned and can be maintained (Gulo, 1982). Therefore it can be concluded that memory is a form of human identity that is different from other creatures, memory becomes a bridge between humans and the past in the form of news (experiences) because memory can make people remember what they get from the senses. Memory is not something you can touch with your arm, observe with your sight, or use other organs of the body, but memory is an abstraction, dynamic in nature, and can be developed based on the information obtained and stored. In this case, the first step of the storage mechanism is to enter the information obtained through learning and then store the information. After saving, the final step is to retrieve the information obtained.

Where students in their memories during the learning activities in the classroom that they receive from educators must be guarded not to lose or forget the learning material that has been distributed. The material substance presented by educators to students during activities in the classroom during the teaching and learning process is of course a lot. So that 
the memory obtained from students is received excessively every day in the learning process activities at school. Students in the subject matter have difficulty seeing, which is a sign that their memory is low, which makes teaching and learning activities in the classroom slow (Putra 2013). MI Ma'arif NU 02 Taman Sari in grade IV for students still have low memory so that students' memory is not high.

MI Ma'arif NU 02 Tamansari based on the results of interviews with homeroom teachers at the fourth grade level of education stated that the memory of students in the class was not all good. Activities in the classroom when the teaching and learning process runs smoothly and well by educators with students where if they have a good memory of the students themselves. However, if teaching and learning activities in the classroom are slow, it is mostly because students have low memory so they will have difficulty learning. Ibu Sulis Fatimah as the fourth-grade homeroom teacher at MI Ma'arif NU 02 Tamansari revealed that students in the class can easily and quickly remember the rhythm of today's songs. However, it is inversely proportional, when the teacher provides learning material in class to students, it must be repeated because students are very difficult to remember learning material.

In the world of education, the learning \& thinking system that is most widely used is the mind map. Mind mapping is a learning method developed by Tony Buzan, head of the Brain Foundation, an expert on brain development, creativity, and the education revolution from the UK since the early 1970s (Windura, 2013). One effort that can overcome this problem is to use a mind mapping model (mind map). Mind maps are a creative note-taking method that makes it easy for us to remember a lot of information. According to Windura, in his book states that the benefits of providing learning activities by using a mind map for students are that students are able to design activities of daily life and students will think easily. Mind maps are used by educators or students to schedule, summarize, think critically, think imaginatively, plan time schedules for activities, cut reading articles, understand and solve science and math story problems, and so on (Widura, 2013).

Success in teaching and learning can be seen from the method and use of appropriate media from a teacher in a lesson that is carried out (Mahampang, 2018). The learning method is a design that has been compiled and then used to carry out the learning process that is determined to add to the quality of learning (Trianto, 1989). The right way to increase student retention is by using the mind mapping method, where one of the advantages of the mind mapping method is that this method can improve students' memory abilities because mind mapping allows students to use two parts of the brain, namely the right brain and the left brain. This note-taking method departs from the results of a study on how the brain processes information. Scientists originally thought that the brain processes and stores information in a linear fashion, much like traditional note-taking methods. But now they find that the brain takes information in a mixture of images, sounds, smells, thoughts, and feelings and breaks it down into a linear form, for example in the form of writing or oration. When the brain remembers information, it is usually done in the form of colorful pictures, symbols, sounds, feelings. (Tony Buzan, 2004).

Research conducted by Ade Fuji Pratiwi showed that there was an increase in children's memory through mind mapping media in group B at Al-Muttaqin Islamic Kindergarten, Jambi City. This is shown by the child's memory after being given action in the 1 st cycle of the 1 st meeting increased to $(28.63 \%)$, the first cycle of the 2 nd meeting to $(34.01 \%)$, the first cycle of the 3rd meeting increased to $(38,02 \%)$ and the first cycle of the 4th meeting increased to (46.66). The average percentage result in the first cycle was $36.83 \%$. This achievement was included in the criteria for starting to develop ( $25 \%-50 \%)$. The average percentage result in cycle II is $77.69 \%$, this achievement is included in the very welldeveloped criteria (75\% -100\%) (Pratiwi, 2017). Meanwhile, research conducted by Laili Rob Rememberun shows that there is a positive relationship between Tony Buzan's mind map 
learning method and retention power. This is evidenced by $\mathrm{r}$ count $>\mathrm{r}$ table, the result of correlation product-moment shows a correlation coefficient of $0.455>0.423$ which means the relationship between Tony Buzan's mind map learning method, based on the $r$ value interpretation table, the value of 0.455 is in the sufficient category (Rob REMEMBER, 2018).

The method of mind-mapping can help students to remember subject matter, concentrate, sort information, and ideas, be creative, use imagination, understand, take notes, control, remain calm, and remain interested in learning material (Buzan, 2008). Mind maps are one of the learning methods, by shortening the learning material that needs to be studied, then assessing the questions summarized into a mind map so that they are easy to understand. (Sugiartolwan, 2004). The mind mapping method is an idea mapping method, describing information in the form of branches of thought and various creative imaginative delusions, which are the meaning of the mind map method. This method is a creative note-taking method that makes it easier for someone to remember information and can foster student creativity when working on mind mapping projects.

According to Tony Buzan, he revealed that the mind map is a method by writing imaginatively accordingly based on the workings of the thinking power that elaborates concepts, using line strokes, various color patterns, sign characters, and sketch illustrations (Buzan, 2004). Mind maps build for children to think, think (imagine), view, design, and sort information carefully. Digits (values), speech, descriptions, numerical questions, and so on are the workings of the left brain in presenting information in short-term characters. Painting illustrations, song rhymes, color motifs, creativity, and imagination are the workings of the right brain in presenting information with a long-term character (Buzan, 2004). The use of the left brain is more dominant in learning activities in the classroom than the right brain. Actually, the right brain and left brain must be balanced so that there is no heavy load in one of them.

According to Fiske and Taylor in their book, Eric Jensen states that certain life images have the greatest impact on students' memory. Neuroscientists believe that this is because the brain pays more attention to contrast and novelty; $90 \%$ of the brain's sensory input comes from peringi (source) image (visual). Furthermore, the brain has a direct and original response to symbols (logos), signs (images), and other simple illustrations (sketches). Therefore, educators can use shapes (topics), paintings (pictures), charts, diagrams, slides, video clips, bulletin board displays, and patterns to learn to attract the brain's animo (interest). For maximum effect, educators can create live posters, mind maps, illustrations, and symbols (icons). Because as mentioned above, vision is an important key for students to remember (remember) the content of learning material (Jensen, 2011). Using a mind map includes the components of color hues, illustrated scribbles (sketches), and line strokes, which are stimuli that can attract students' interest (interest) to pay attention (observe them). So start the charts that have been made to arouse students into focus and concentration on the study of the subject of thought.

Based on the explanation above, the researcher feels interested in carrying out more in-depth research and is presented in a scientific paper in the form of field research entitled "The Effect of the Mind Map Method on the Memory of Students in Thematic Learning".

\section{RESEARCH METHODS}

In this quantitative research, this study use experimental methods. The preexperimental approach is used in this study. The pre-experimental design used was One Group Pretest Posttest. This research uses one group without needing a control group (Sugiyono, 2016). The independent variable in this study is the method of mind mapping represented by the letter $\mathrm{X}$, and the dependent variable in this study is the memory of students represented by the letter $Y$. This study uses quantitative data types about student responses to 
thematic learning with the quantitative data mind map method. required is a test result. Sources of data in this study are divided into two, namely primary and secondary data sources. The primary data sources in this study were fourth-grade students at MI Ma'arif NU 02 Tamansari. Meanwhile, the secondary data source is the teaching and learning process. The population of this study was all fourth-grade students, totaling 23 students, 13 female students, and 10 male students.

Observation, interviews, documentation, and tests are data collection techniques used in this study. When the learning took place, this research was carried out as an observation activity. The interview was conducted in an unstructured manner as supporting data for the research. While the documentation in this study is collecting information data related to the results of the students' mind maps, the results of the pretest and posttest, and documentation in the form of photos of the implementation of action activities. While tests are needed in research to determine the initial abilities of students before and after being given action. The test used is in the form of short stuffing questions. Short stuffing questions are used to measure the ability to remember.

Memory indicators include memorizing (receiving), storing, and producing. Memorizing (receiving), namely attaching impression responses or understanding to ourselves so that these impressions can be stored and reproduced. Saving is organizing and maintaining what we have attached so that one day we can use it because saving is a very important memory job. And the last indicator of memory is production, which is raising awareness of what has been stored in the subconscious or unconscious parts of our psyche. (Rahman, 2012).

In addition to the activity indicator, the instrument in this study has an important position in the research because the instrument plays a role in the data collection process. Valid and reliable instruments can also produce valid and reliable data so that they lead to conclusions that are in accordance with the actual situation (Yusup, 2018). The types of validation for this research instrument are content validity, construct validity, and empirical validation. The reality of the instrument was tested using the help of SPSS version 24.00. A reliability test can be done with Cronbach's Alpha. If the alpha value is greater than 0.6, the instrument in this study can be declared reliable (Trihendaradi, 2007).

The instrument used in this study was a test instrument. The test instrument is measuring because it contains questions or statements whose alternative answers have a certain standard answer in the form of true or false or an answer scale. The test used as a research instrument was in the form of a short entry. The making of test questions is based on basic competencies which are translated into question indicators in the form of question grids. The question indicators that are made are adjusted to the basic competencies of thematic learning in grade IV.

The results of the calculation of reliability on memory problems can be seen in the following table:

Tabel 1. Reability Statistics

\begin{tabular}{|c|c|}
\hline Cronbach's Alpha & N of items \\
\hline 0.931 & 25 \\
\hline
\end{tabular}

Based on the table above, the value of the instrument reliability coefficient is 0.931 . This research instrument can be declared reliable because the value calculated is greater than $r$ table. 0.931>0.404. This research instrument has high reliability based on the interpretation table of the $r$ value so that the test questions are suitable for use in research.

This study uses two kinds of statistics, namely descriptive statistics and inferential statistics. First, this research test uses the analysis prerequisite test in the form of the 
normality test, namely using the one-sample t-test or analysis of variance and the t-test for two samples. This normality test will determine the conclusions, those are:

1. If the significance value $>0.05$, the data is normally distributed

2. If the significant value $<0.05$, the data is not normally distributed.

The homogeneity test in this study used the Levene test with a significance level of $5 \%$ with the help of SPSS 24.00. In this study, researchers used the Test of Homogeneity. The homogeneity test aims to determine whether the data obtained has the same variant or not. The homogeneity test criterion is if the significance value is greater than 0.05 , the data is declared homogeneous. Second, the research hypothesis testing includes hypothesis testing with t-test. as for the t-test used was the paired sample t-test. The paired sample t-test is part of the hypothesis test or comparison test. In making decisions, it can be seen after analyzing data, where:

a. If the significance value $>0.05$ then $\mathrm{H}_{a}$ is accepted

b. If the significance value $<0.05$ then $\mathrm{H}_{0}$ is rejected.

\section{RESEARCH RESULTS AND DISCUSSION}

The initial stage carried out to determine the effect of treatment in this study was to conduct an initial ability test. This test is done by pretesting the students. After the pretest was carried out, the students' score were still low with the highest score of 72 and the lowest score of 32, the average score obtained in the pretest was 53.04. Through these results, it is evident that students at MI Ma'arif NU 02 Tamansari need a method that can make it easier for students to remember and memorize material in thematic learning.

After being given a pretest and a low score, then a treatment or treatment is carried out, namely learning with the mind map method. The treatment was carried out 2 times, where 1 meeting was $2 \times 35$ minutes. After being given the treatment, a posttest was carried out to see the improvement in memory as seen from the posttest score. The highest score was 96 , the lowest score was 72 , with an average of 85.74. Through the acquisition of this valuable data, it proves that there is an increase in student scores before action is given and that the average score of students has reached the specified KKM standards.

The mind map method is able to influence the improvement of students' memory. This is in accordance with the research conducted by Desy Rahmi Astuti in the title "Improving Student Memory with the Mind Mapping Method in Social Studies Subjects", this research shows that there is an increase in the memory of students on subjects. IPS seen from the average value of pretest cycle 1 was 59.9 and increased after posttest 1 was 69.8 and posttest II increased by 81.2. It is said that the use of mind mapping in social studies lessons can help students remember what they have learned.

The mind map method can improve student memory in the learning process in the classroom, be able to make students more concentrated in class, express ideas, process information, be creative, optimize imagination, understand, stay calm, and be enthusiastic about the learning being conveyed (Buzan, 2008). As mentioned by Buan, besides being able to improve children's memory, the mind map method is also able to make students more concentrated in accepting learning in class. Through this method, learning can be conveyed in a directed manner. The increase in student concentration in learning with the mind map method can be seen from the increase in student activeness in the treatment given by the teacher. In the second treatment, students were asked to make a mind map about diversity in my country. In the learning process using the mind map method in grade IV, students seem to be very active in creating and expressing their ideas. The activeness of students can also be seen when they ask educators about material that cannot be understood. 
The mind map is a learning method that is used by summarizing the learning material into a mind map making it easier for students to understand it. (Sugiartowlan, 2004). As the theory stated by Tony Buzan, the mind map is a learning method that is done by taking creative notes, which in practice uses the work of the brain by developing concepts using striking lines, color patterns, symbols, and illustrations (Buzan, 2004). Learning by maximizing the five senses and positive emotions has influence on students' long-term memory, so that memory can be stored for longer. The mind map is a method that is considered quite good to use in the learning process because it uses illustrations (sketches), cross lines, symbols, and color tones that can maximize some of the child's senses. The use of mind maps in the learning process can be achieved effectively because the mind map method encourages students to take advantage of more than one sense and be able to use both the right and left brains. Through the mind map method, students can get information easily and pleasantly so that this method will help students understand the learning material presented by the educator, and students are able to remember (view) the material presented longer.

In the final reflection stage of the learning process carried out by the teacher in class IV MI Ma'arif NU 02 Tamansari, students revealed that they were happy with the learning method conveyed by the teacher, through the mind map method students did not only listen to the teacher's explanation conventionally, but the students required to immediately learn to understand the material, as well as pour ideas, and create ideas into a pattern of pictures freely. From these activities, learning not only activates aspects of student knowledge but also students' attitudes and motor skills. Through this method, students are given the freedom to be creative in pouring ideas, making pictures, symbols, writing, combining colors into one interesting concept of knowledge. So that this knowledge can look more fun and students do not get bored in interpreting the learning material delivered by educators. Based on the results of observations by researchers during the learning process in the classroom using the mind map method, it can be seen that the class atmosphere becomes more lively, fun, and also remains conducive.

Based on the explanation above, it is in accordance with the theory put forward by Tony Buzan which states that mind maps can foster student creativity and can make students more concentrated is true (Buzan, 2008). However, in this study, researchers focused more on knowing the effect of the mind map method on student retention. So that in the next step, the researcher conducted a significance test of the treatment. The significance test of the treatment is important for making decisions from the hypothesis. The t-test results from the pretest-posttest values obtained the Sig. (2-tailed) is smaller than 0.05, namely 0.000. Based on these data, it can be concluded that $\mathrm{Ha}$ is accepted and $\mathrm{HO}$ is rejected, which proves the influence of the mind mapping method on student retention in the thematic learning process. The t-test results show (imply) that there are differences in students' memory before and after using mind mapping. This means that the mind mapping method will affect the memory of fourth-grade students of MI MI Ma'arif NU 02 Tamansari.

Based on the results of the analysis and the theory which states that the mind map method has an influence on students' memory, it is proven through this research. With the mind map, students can be flexible in remembering the learning material presented by the educator, and the mind map is able to train students to be more creative and maximize both of their brains in the learning process.

\section{CONCLUSION}

Based on the t-test using SPSS 24.00 in this study, the results of the significance test were 0.000 which was smaller than 0.05 . Therefore, Ha received and $\mathrm{H} 0$ is rejected. Thus, it 
is concluded that the method of mind mapping affects students' memory in the fourth-grade thematic learning of MI Ma'arif NU 02 Tamansari, even semester 2018/2019.

\section{REFERENCES}

Astuti, Desi Rahmi. (2018). Meningkatkan Daya Ingat Siswa dengan Metode Mind Mapping Pada Pembelajaran IPS. Jurnal Riset Mahasiswa Bimbingan dan Konseling, 4(10).

Bimo, Walgito. (2010). Pengantar Psikologi Umum. Yogyakarta: CV Andi Offset.

Buzan, Tony. (2004). Mind Map Untuk Meningkatkan Kreatifitas. Jakarta: PT Gramedia Pustaka Umum.

Buzan, Tony. (2008). Buku Pintar Mind Map. Jakarta: Gramedia Pustaka Utama.

Gulo, Dali. (1982). Kamus Psikologi. Bandung: Tonis.

Jannah, Raihanatul., Syarifah Salmah, Barkah Alida Yahya. (2017). Pengaruh Penggunaan Strategi Lari Kanan Kiri Benar Salah Terhadap Hasil Belajar Siswa pada Pembelajaran Bahasa Inggris Kelas IV di MIN Pemurus dalam Banjarmasin. AL-ADZKA: Jurnal Ilmiah Pendidikan Guru Madrasah Ibtidaiyah. VII(01). 75-96.

Jensen, Eric. (2011). Pembelajaran Berbasis Otak. Jakarta: PT Indeks.

Juwantara, Ridho Agung. (2019). Analisis Teori Perkembangan Kognitif Piaget pada Tahap Anak Usia Operasional Konkret 7-12 Tahun dalam Pembelajaran Matematika. $A L$ ADZKA: Jurnal Ilmiah Pendidikan Guru Madrasah Ibtidaiyah. 9(01). 27-34.

Lubis, Nur Fitriani dan Zulkifli Simatupang. (2014). Peningkatan Daya Retensi Peserta Didik terhadap Konsep-Konsep Biologi Melalui Pemanfaatan Media Adobe Flash pada Model Pembelajaran Langsung. Prosding SemNas Biologi dan Pembelajarannya Program Studi Pendidikan Biologi Universitas Negeri Medan.

MA, S. Nasution. (2010). Kurikulum dan Pengajaran. Jakarta: Bumi Aksara.

Mahmudah. (2018). Pengaruh Media Audio terhadap Keterampilan Menyimak dan Berbicara Bahasa Arab. Jurnal Tarbiyah: Jurnal Ilmiah Kependidikan. 7(2). 75-85.

Majid, Abdul. (2004). Pembelajaran Tematik Terpadu. Bandung: PT Remaja Rosda Karya.

Pratiwi, Ade Fuji. (2017). "Peningkatan Daya Ingat Anak Usia Dini Melalui Media Mind Mapping Pada Kelompok B di TK Islam Al-Muttaqin Kota Jambi”. Skirpsi. Jambi: Jurusan Pendidikan Guru PAUD Universitas Negeri Jambi.

Putra, Arisdea Tri., Hairida, Ira Lestari dkk. (2013). Pengaruh Multimedia Berbasis Mind Mapping terhadap Hasil dan Retensi Belajar Peserta Didik pada Materi Hidrokarbon. Jurnal Program Studi Pendidikan Kimia Fakultas Ilmu Pendidikan Untan.

Rahmi, Rudiana. (2018). Korelasi Kegiatan Ice Breaking dengan Motivasi Belajar Peserta Didik dalam Proses Pembelajaran Tematik. AL-ADZKA: Jurnal Ilmiah Pendidikan Guru Madrasah Ibtidaiyah. VIII(02). 151-160.

Robingatun, Laili. (2018). "Hubungan Antara Metode Pembelajaran Mind Map Tony Buzan Terhadap Daya Retensi Peserta Didik Kelas IV SDIT Salsabila 3 Banguntapan”. Skripsi. Yogyakarta: Jurusan Pendidikan Guru Madrasah Ibtidaiyah Fakultas Ilmu Tarbiyah dan Keguruan UIN Sunan Kalijaga Yogyakarta.

Rusman. (2011). Model-Model Pembelajaran: Mengembangkan Profesionalisme Guru. Jakarta: Rajawali Press.

Sugiyono. (2016). Metode Penelitian Pendidikan : Pendekatan Kuantitatif, Kualitatif, dan $R \& D$. Bandung: Alfabeta.

Sugiartolwan. (2004). Mengoptimalkan Daya Kerja Otak dengan Berpikir Holistik dan Kreatif. Jakarta: PT Gramedia Pustaka.

Suryosubroto, B. (2009). Proses Belajar Mengajar di Sekolah: Wawasan Baru, Beberapa Metode Pendukung dan Beberapa Komponen Layanan Khusus. Jakarta: Rineka Cipta.

Trianto. (1989). Model Pembelajaran Terpadu. Jakarta: Bumi Aksara.

Trihendaradi, C. (2007). Langkah Mudah Menguasai SPSS 15. Yogyakarta: CV. Andi Offset. 
Yusup, Febrianawati. (2018). Uji Validitas dan Reliabilitas Instrumen Penelitian Kuantitatif. Jurnal Tarbiyah: Jurnal Ilmiah Kependidikan, 7(1), 17-23.

Windura, Sutanto. (2013). First Mind Map. Jakarta: Gramedia. 